\title{
Advanced Functions of a Modern Power Source for GMAW Welding of Steel
}

\author{
Ladislav Kolařík ${ }^{1}$, Marie Kolaříková ${ }^{1}$, Karel Kovanda ${ }^{1}$, Marek Pantůček ${ }^{2}$, Petr Vondrouš \\ ${ }^{1}$ CTU in Prague, Faculty of Mechanical Engineering, Department of Manufacturing Technology, \\ Technická 4, 16607 Praha 6, Czech Republic \\ ${ }^{2}$ Migatronic CZ, a.s., Tolstého 451, 41503 Teplice 3, Czech Republic
}

Correspondence to: ladislav.kolarik@fs.cvut.cz

\begin{abstract}
This paper evaluates the use of a modern welding power source equipped with advanced arc control functions. At the Laboratory of Welding Technologies of CTU in Prague we have focused on GMAW welding of steel using Sigma Galaxy, a modern welding power source produced by Migatronic. Sigma Galaxy is equipped with functions called Intelligent Arc Control and Sequence Repeat. According to the manufacturer, controlling an arc by these functions should significantly stabilize the welding process, lower the heat input and the deformation, and improve the weld quality. To evaluate the benefits of these functions completely, single V butt welds were performed on S275J2 structural steel $10 \mathrm{~mm}$ in thickness (2 weld layers: root + capping layer) in PF and PG positions. Welding was monitored by the Welding Information System, and was compared with standard GMAW welding. The results have shown that these "intelligent" functions offer significant advantages for steel welding, especially in vertical and overhead positions, because they lower the heat input and improve the weld metal control.
\end{abstract}

Keywords: welding, GMAW, IAC, sequence repeat.

\section{Introduction}

The aim of this study is to investigate the main advantages of using a modern GMAW welding source equipped with special pulse control functions. The main goal is to measure and present the influence of pulse control, and to compare independent experimental results with the information advertised by the welding source manufacturer.

In present-day industrial welding practice,

GMAW (Gas Metal Arc Welding) is the most widelyused welding technology. As in the case of any manufacturing technology, what industry requires from the GMAW welding process is increased efficiency, lower costs and greater welding speed, while achieving high-quality, improved weld quality, and not requiring highly-qualified welders. Other industrial requirements for the GMAW process are e.g. overhead welding (PD, PE) and vertical welding (PF, PG), bridging wide root openings, and an increased melting rate. Another important trend is the application of GMAW in domain of GTAW (Gas Tungsten Arc Welding) welding, i.e. welding of high strength steels, welding of non-ferrous materials, thin sheets and heterogeneous joints.

Developments in modern microelectronics have led to rapid advances in welding sources. With the use of fast microelectronic circuits, the speed of welding process control and welding parameter adjustment has been increased tremendously, and dynamic control over arc and molten metal transfer has become possible. Research and development carried out by manufacturers of welding sources focuses on rapid optimal control of the welding parameters during welding. Modern welding sources are equipped with special control functions of arc and molten metal transfer, focusing on two basic areas. The first area of focus is on welding thin metal sheets $(0.5-3 \mathrm{~mm})$, and the second is on high-productivity thick metal sheet welding (over $5 \mathrm{~mm}$ ).

1. Thin metal sheet welding: the top priority in thin sheet welding is to stabilize and lower the heat input to reduce the risk of burn-through, to reduce warping, improve melt pool control, and reduce spatter. This can mainly be achieved by stabilizing and controlling the arc. With this in mind, many welding source manufacturers have developed pulse control functions incorporated into their welding sources, e.g. CMT (Fronius), STT (Lincoln Electric), Cold Arc (EWM), SAT (ESAB) $[1,7,8]$.

2. Thick sheet welding: the top priority is to maximize the weld metal deposition rate when the heat input and spatter is low. Welding 
source manufacturers have developed pulse control functions for sheets over $5 \mathrm{~mm}$,e.g. Force Arc (EWM), Power Arc (Migatronic), Aristo SuperPulse (ESAB) tandem welding, T.I.M.E. (Fronius) [6, 9, 10].

A Sigma 400 Galaxy Migatronic welding source equipped with an IAC (Iintelligent Arc Control) function and Sequence Repeat was used for our study. A brief introduction to these functions, as advertised by Migatronic, follows:

\subsection{Function IAC - intelligent arc control}

This function focuses on welding of thin sheets and on root welds, bridging wide and uneven weld gaps, and welding in vertical downward PG position. This function offers lower spatter, high stability, low heat input. The IAC function changes the standard short arc current and voltage in time. During molten metal drop separation, when short circuiting is finished, a low value current pulse is used to suppress spatter to a significant extent $[2,3]$.

\subsection{Function sequence repeat}

This function combines two molten metal transfer modes periodically, e.g. a combination of short arc mode and pulsed transfer mode. The short arc mode has lower welding parameters (less heat input), and the pulsed transfer mode has higher parameters (higher heat input). This is advantageous for welding in difficult positions PC, PD, PE, PF or PG. Also when applied to a $\mathrm{V}$-joint butt weld, the welder can make a weave movement without dwelling over the beveled face. This dwell is usually needed in order to distribute the heat as necessary. A pulsed transfer is used when the torch is over the beveled faces (to assure side wall fusion), and a short arc is used when not (the central part of the weld, to prevent excessive reinforcement or burn through). Continuous weave movement is therefore possible, making weave movement easier for the welder $[2,4]$.

\section{Experimental}

Robotic welding was carried out in the robotic cell in the welding laboratory of CTU in Prague, equipped with a Migatronic Sigma 400 Galaxy power source with IAC and Sequence Repeat functions. Improvements resulting from the use of the IAC function and the Sequence Repeat function were evaluated on the basis of a comparison of samples A and B welded in difficult vertical positions PF, PG. Sample A was welded using these functions, while sample B was welded without their use, using typical welding parameters and short arc transfer mode.

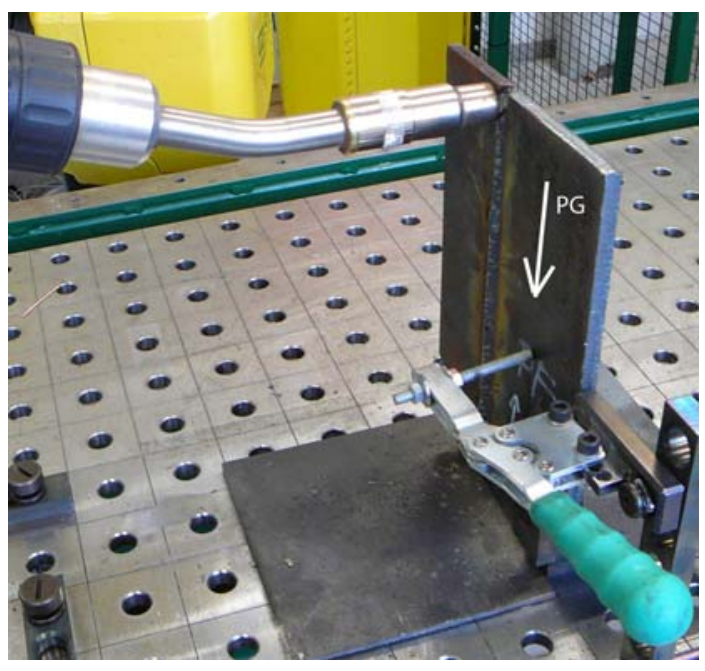

Figure 1: Weld sample-welding position PG

A sample $10 \mathrm{~mm}$ in thickness needed two layers, a root layer and a capping layer carried out with the weave function. In order to observe the evolution of $U, I$ in time, the WIS (Welding Information System) monitoring unit was connected to the welding source to record the time evolution of the welding parameters $I, U, v$, etc.

A root weld was performed in vertical downward PG position for samples $A$ and $B$, see Figure 1. PG position is considered a difficult position for root welds, because it does not offer good penetration and often has the problem of insufficient root penetration. The capping layer was performed in vertical upward position PF.

S275J2 structural steel $10 \mathrm{~mm}$ in thickness was used. The composition and the basic properties are shown in Table 1. OK Autrod 12.56, diameter $1 \mathrm{~mm}$, supplied by ESAB, a typical filler material for these steels, was used. Base metal sheet, $200 \times 80 \mathrm{~mm}$ in size, thickness $10 \mathrm{~mm}$, was used. V-joint with groove angle $70^{\circ}$ and root opening $3.2 \mathrm{~mm}$. The shielding gas was M21, a mixture of $82 \% \mathrm{Ar}+18 \% \mathrm{CO}_{2}$.

Table 1: Base metal composition and mechanical properties — S275J2 state according to DIN EN 10025-2 [5]

\begin{tabular}{|c|c|c|c|c|c|}
\hline C & Mn & Si & P & S & Al \\
\hline Max. 0.22\% & Max. 1.6 \% & Max. 0.55\% & Max. 0.035\% & Max. 0.035\% & $0.01-0.06 \%$ \\
\hline \multicolumn{2}{|c|}{$R_{m}[\mathrm{MPa}]$} & \multicolumn{2}{|c|}{$R_{p 0,2}[\mathrm{MPa}]$} & \multicolumn{2}{c|}{$A_{5}[\%]$} \\
\hline \multicolumn{2}{|c|}{$410-560$} & \multicolumn{2}{|c|}{275} & \multicolumn{2}{c|}{21} \\
\hline
\end{tabular}




\section{Results}

The welding parameters used for samples A and B are shown in Table 2. Setting optimum parameters for A sample was easier, and the first sample was already successful. Creating a good weld without advanced functions, with a standard short arc required three B test samples, because of the difficult root welding.

\subsection{Root weld - setting the welding parameters}

To create a sound weld, it was necessary to adjust the welding parameters, especially for sample B. The welding parameters were: welding speed $0.10 \mathrm{~m}$. $\min ^{-1}$, current $80 \mathrm{~A}$, voltage $16 \mathrm{~V}$, weave movement setting: frequency $2 \mathrm{~Hz}$, amplitude $1.5 \mathrm{~mm}$, dwell $0.4 \mathrm{~s}$.

Sample A: Function IAC was used with the parameters stated above. The weld had sufficient root penetration, and also sufficient penetration on both faces, see Figure 4. The arc was stable. The molten pool was not dripping. No spatter was found. The weld quality was high, without a defect.

Sample B: When current $80 \mathrm{~A}$ was set up on the welding source without using the IAC function, the welding process was very unstable. The arc was unstable, the heat input was insufficient, the joint faces were not completely fused. Only one joint face was melted. To stabilize the process and to fuse the two join faces, the current needed to be increased twice, to $100 \mathrm{~A}$ and to $130 \mathrm{~A}$. At $130 \mathrm{~A}$, the welding process was stabilized, but the root of the weld was concave in shape (welding defect: root concavity), as shown in Figure 6. This is in concordance with known fact that a short arc in $\mathrm{PG}$ position is not suitable for forming a root weld. PF position would be more suitable.

\subsection{Capping weld - setting the welding parameters}

The capping welds were performed in vertical upward PF position.

Sample A: Function Sequence Repeat was used for the capping layer. Function Sequence Repeat changed the metal transfer mode periodically from IAC short arc to pulse transfer, see Figure 3. The setting of the function was: IAC short arc transfer $85 \mathrm{~A}$ for a period of $0.6 \mathrm{~s}$, pulsed arc transfer $150 \mathrm{~A}$ for a period of $0.3 \mathrm{~s}$. The results are shown in Figure 5 .

During the pulsed arc phases (higher heat input), the torch heated up the weld faces. During IAC short arc (lower heat input), the torch was in between the faces.

Sample B: To melt both joint faces well, the current needed to be increased to $145 \mathrm{~A}$. The results are shown in Figure 7.

The welding parameters that were set are shown in Table 2.

He measured time evolution of current and voltage for a root weld of sample A and sample B3 is shown in Figure 2. This picture shows the difference between the standard short arc transfer and the IAC function short arc transfer.

Table 2: Welding parameters

\begin{tabular}{|c|c|c|c|c|c|c|c|c|}
\hline Sample & $\begin{array}{c}\text { Function, } \\
\text { metal } \\
\text { transfer }\end{array}$ & $\begin{array}{l}\text { Weld } \\
\text { pass }\end{array}$ & $\begin{array}{c}\text { Current } \\
{[\mathrm{A}]}\end{array}$ & $\begin{array}{c}\text { Voltage } \\
\text { [V] }\end{array}$ & $\begin{array}{l}\text { Wire feed } \\
{\left[\mathrm{m} \cdot \mathrm{min}^{-1}\right]}\end{array}$ & $\begin{array}{l}\text { Welding } \\
\text { speed } \\
{\left[\mathrm{mm} \cdot \mathrm{s}^{-1}\right]}\end{array}$ & $\begin{array}{l}\text { Heat input } \\
{\left[\mathrm{kJ} \cdot \mathrm{mm}^{-1}\right]}\end{array}$ & Result \\
\hline & IAC & root & 80 & 15.5 & 2.5 & \multirow{6}{*}{1.7} & 0.59 & $\begin{array}{c}\text { OK } \\
\text { Figure } 4\end{array}$ \\
\hline $\mathrm{A}$ & $\begin{array}{l}\text { Sequence } \\
\text { Repeat }\end{array}$ & capping & $\begin{array}{l}85 \text { short arc } \\
150 \text { pulsed }\end{array}$ & $\begin{array}{l}16 \\
26.4\end{array}$ & $\begin{array}{l}2.6 \\
6.7\end{array}$ & & $\begin{array}{c}0.66(0.6 \mathrm{~s}) \\
1.90(0.3 \mathrm{~s}) \\
\text { AVG } 1.1\end{array}$ & $\begin{array}{c}\text { OK } \\
\text { Figure } 5\end{array}$ \\
\hline B1 & Short arc & root & 80 & 16.3 & 2.5 & & 0.63 & $\mathrm{NG}$ \\
\hline B2 & Short arc & root & 100 & 17 & 3.3 & & 0.82 & $\mathrm{NG}$ \\
\hline \multirow[t]{2}{*}{ B3 } & Short arc & root & 130 & 18.5 & 4.9 & & 1.16 & $\begin{array}{c}\text { OK } \\
\text { Figure } 6\end{array}$ \\
\hline & Short arc & capping & 145 & 19.2 & 5.6 & & 1.34 & $\begin{array}{c}\text { OK } \\
\text { Figure } 7\end{array}$ \\
\hline
\end{tabular}



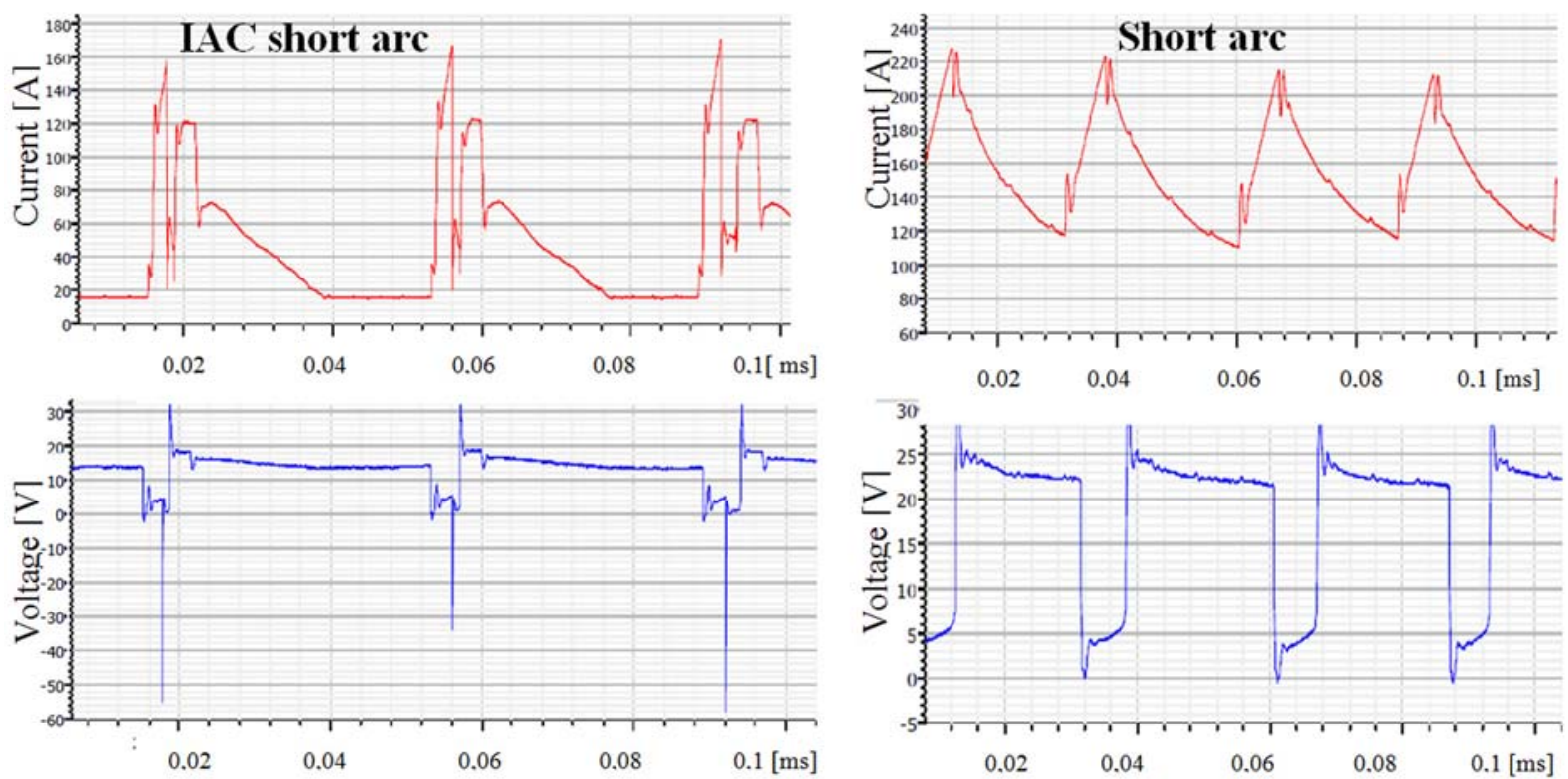

Figure 2: Current, voltage time evolution for root weld - Left: Sample A - IAC function 80 A, Right: Sample B - short arc transfer 130 A

\section{Current $[\mathrm{A}]$}
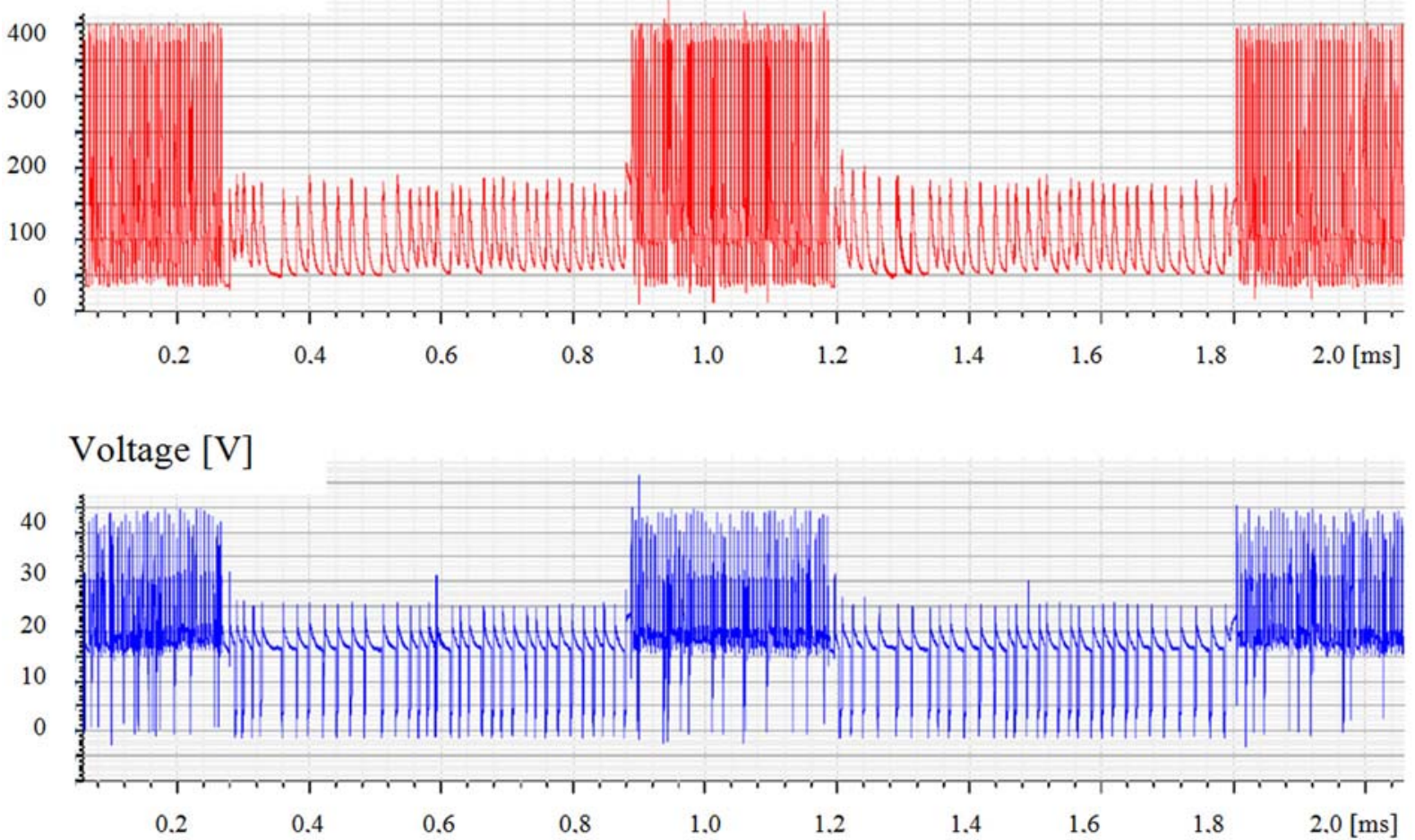

Figure 3: Current, voltage time evolution for the Sequence Repeat weld

Short arc transfer (right side) — when the metal drop touches the weld pool, the current rises to maximum values, and the voltage drops to $0 \mathrm{~V}$. During short cutting there is no arc, and the current rises to the maximum value limited by the power source.
Using the IAC function (left side), the voltage and current time evolution is distinctly different from the standard short arc. The current rises during the shortcut, but after a certain time the power source sharply reduces the voltage, as a result of which 
Table 3: Measured weld geometry

\begin{tabular}{|c|c|c|c|c|c|}
\hline Sample & $\begin{array}{c}\text { Weld } \\
\text { width } \\
{[\mathrm{mm}]}\end{array}$ & $\begin{array}{c}\text { Weld } \\
\text { reinforcement } \\
{[\mathrm{mm}]}\end{array}$ & $\begin{array}{c}\text { Root } \\
\text { width } \\
{[\mathrm{mm}]}\end{array}$ & $\begin{array}{c}\text { Root } \\
\text { reinforcement } \\
{[\mathrm{mm}]}\end{array}$ & $\begin{array}{c}\text { HAZ width } \\
\text { at root } \\
{[\mathrm{mm}]}\end{array}$ \\
\hline A & 11 & 1.9 & 4 & 0.3 & 14 \\
\hline B3 & 12 & 1.8 & 6 & -0.5 & 16 \\
\hline
\end{tabular}

the current is also reduced. This sharp energy drop slows down the melt drop transfer, and the spatter is reduced significantly. The voltage and current are raised to start the arc again.

The weld geometry for sample A, B are shown in Table 3. The lowest width of HAZ at the root was measured for sample A, welded with the IAC function (80 A), $14 \mathrm{~mm}$. Sample B for the same current $(80 \mathrm{~A})$ had lack of penetration and lack of fusion. When the current was increased to $130 \mathrm{~A}$ to reach acceptable penetration and fusion, the HAZ size increased to $16 \mathrm{~mm}$.

\section{Conclusion}

The experiment affirmed some advantages of the IAC function short arc over the standard short arc for welding in difficult positions (PG), because the root shape has improved. The IAC function controls the voltage and current, so that the heat input into the weld can be greatly reduced. The arc is much more stable, even for low arc parameters. It has been proved that the heat-affected zone is smaller and that spatter is suppressed.

Function sequence repeat is advantageous for filling and capping weld passes, because the total heat input is reduced by controlling the voltage and current evolution. A good weld was achieved in PF position, and the heat affected zone size was smaller than for a standard short arc weld.

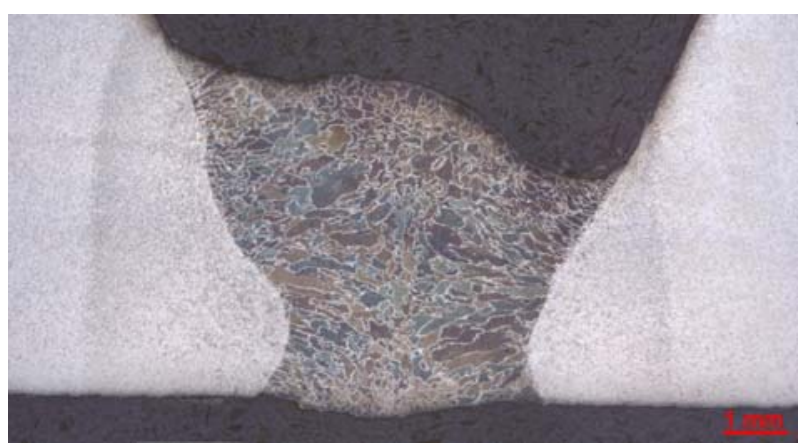

Figure 4: Sample A — root welded with IAC 80 A

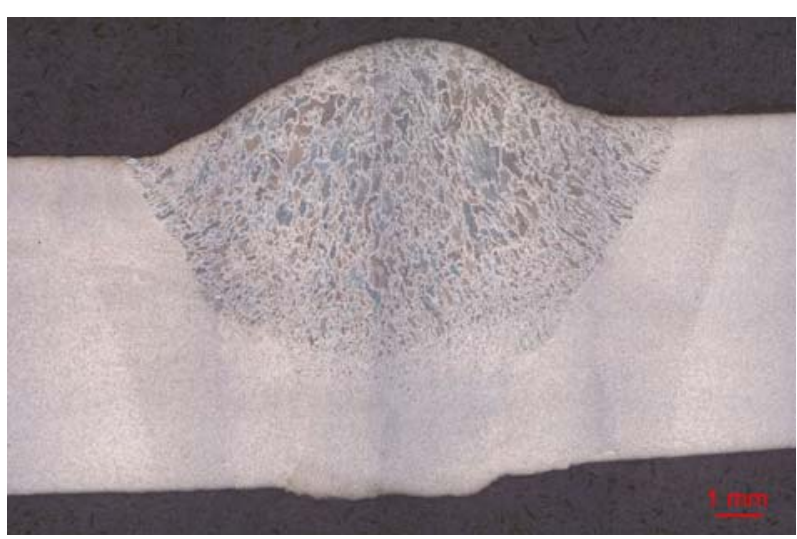

Figure 5: Sample A - capping layer welded with Sequence repeat $85 \mathrm{~A} / 150 \mathrm{~A}$

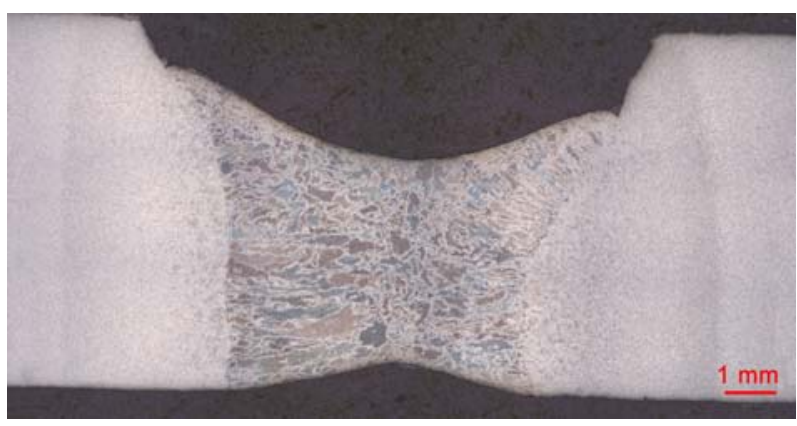

Figure 6: Sample B3 — root weld, short arc 130 A

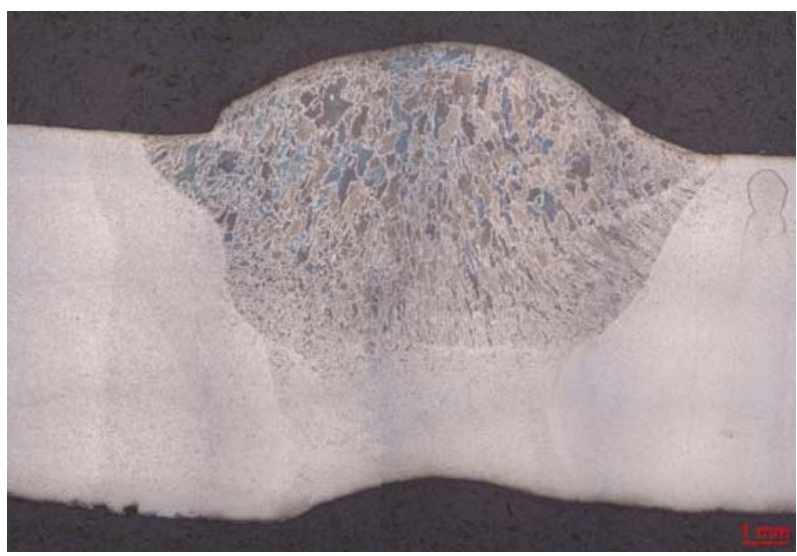

Figure 7: Sample B3 - capping layer, short arc $145 \mathrm{~A}$ 
The development of electronics and programming has enabled the creation of special functions that can considerably improve the behavior of arc and melt transfer, making the welding stable with lower parameters. These functions certainly improve some aspects of the welding process, and they also facilitate the work of welders, by making it easier to set the parameters and to perform welds in difficult positions.

\section{Acknowledgement}

This research was supported by grant no. SGS OHK 2-038/10.

\section{References}

[1] Kolařík, L. a kol.: GMAW svařování ocelových materiálů metodou force arc. TechMat 2011. Pardubice : Univerzita Pardubice, 2011, s. 184-189. ISBN 978-80-7395-431-4.

[2] ČSN EN ISO 6947. Syařování a př́buzné procesy - Polohy svařování. Praha : Český normalizační institut, listopad 2011.

[3] Oddělení výzkumu a vývoje, Migatronic A/S. Intelligent Arc Control - proces pro snižování rozstřiku a vneseného tepla při zkratovém přenosu. Svět svaru, 2011, Vol. 15, No. 3, p. 12-14. ISSN 1214-4983.
[4] Havelka, P.: Vývoj svařování studeným obloukem. Svět svaru, 2011, Vol. 15, No. 1, p. 12. ISSN 1214-4983.

[5] Furbacher, I., Macek, K., Seidl, J. a kol.: Lexikon technických materiálio, sv. 1., Praha : Verlag Dashöfer, 2001.

[6] FRONIUS: Rozšiřte si vědomosti [online]. 2009 [cit. 2004-9-13]. http://www.fronius.com/cps/rde/xchg/ SID-77958394-23586247/fronius_ceska_republika/ hs.xsl/29_104.htm

[7] LINCOLN ELECTRIC. Surface Tension Transfer [online]. 2006 [cit. 2012-03-29]. http://www.lincolnelectric.com/assets/en_US/ Products/literature/NX220.pdf

[8] ESAB. Swift Arc Transfer [online]. 2009 [cit. 2012-03-29]. http://products.esab.com/ ESABImages/Swift_Art_Transfer_final.pdf

[9] FRONIUS. TIME and TimeTwin welding [online]. 2011 [cit. 2012-05-29]. http://www.fronius.com/cps/rde/xchg/ fronius_international/hs.xsl/ 79_9163_ENG_HTML.htm

[10] MIGATRONIC. Improved quality and higher productivity from energy-dense PowerArc technology for thick-plate welding [online]. 2010 [cit. 2012-03-29]. http://www.migatronic.com/ default.aspx $? \mathrm{~m}=4 \& \mathrm{i}=115 \& \mathrm{pi}=1 \& \mathrm{pr}=0$ 